\title{
Are Donor Countries Giving More or Less Aid?
}

Sanjeev Gupta, Catherine Pattillo, and Smita Wagh 



\title{
IMF Working Paper
}

\author{
African Department
}

\section{Are Donor Countries Giving More or Less Aid?}

\author{
Prepared by Sanjeev Gupta, Catherine Pattillo, and Smita Wagh ${ }^{1}$
}

January 2006

\begin{abstract}
This Working Paper should not be reported as representing the views of the IMF. The views expressed in this Working Paper are those of the author(s) and do not necessarily represent those of the IMF or IMF policy. Working Papers describe research in progress by the author(s) and are published to elicit comments and to further debate.

The volume of foreign aid has increased during the last four decades, albeit with interruptions in certain years. Over time, the major recipients have changed: while the share of aid to Asia has diminished since the 1980s, that destined for sub-Saharan Africa has grown. There is some evidence that, since the late 1990s, debt relief has assumed a larger share of the increased aid flows to sub-Saharan Africa. The share of technical cooperation-a component of aid that is viewed as being driven by donors - has risen. More recently, there has been an increased emphasis on providing budget support to recipient governments, especially in the form of debt relief. Donor harmonization, national ownership of development plans, and sound policies on the part of the recipients are crucial for the aid to be effective in reducing poverty.

JEL Classification Numbers: F02, F35
\end{abstract}

Keywords: Foreign Aid, Donor Countries, Budget Support, Technical Cooperation Author(s) E-Mail Address: SGupta@imf.org, CPattillo@imf.org, SWagh@imf.org

\footnotetext{
${ }^{1}$ We wish to thank Robert Powell and Erwin Tiongson for many helpful suggestions on the earlier versions of the paper. This paper is forthcoming in the Review of Development Economics.
} 


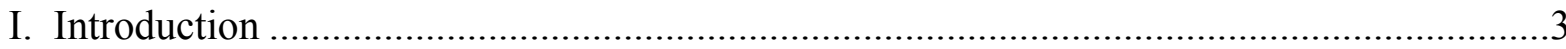

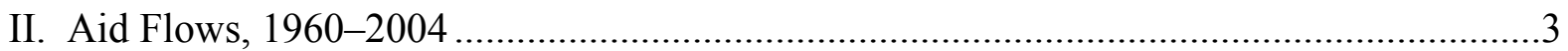

III. Aid Flows, by Destination and Donor Targeting ...................................................

IV. Composition of Aid Flows and National Ownership of Development Strategies............11

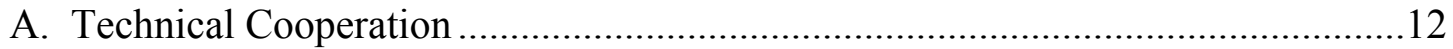

B. Budget Support and Program Assistance Versus Project Aid..............................15

V. Aid Volatility and Predictability of Development Financing .......................................18

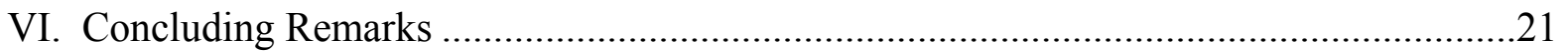

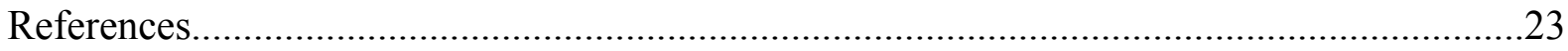

Figures

1. Real Flows of Official Development Assistance, 1960-2004 .........................................4

2. Donor Share in Total Official Development Assistance (ODA) .......................................5

3. Aid Effort Over Time for the Top Three and Bottom Three Donors of 2004 ....................5

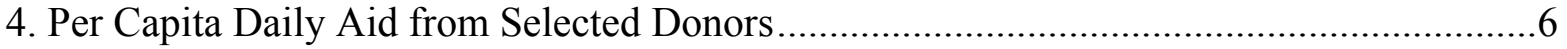

5. Bilateral Grants as a Share of Total ODA ................................................................... 7

6. Real Flow of Aid, by Recipient, 1960-2003 ................................................................. 10

7. Composition of Aid....................................................................................................... 12

8. Composition of Technical Cooperation Expenditures from DAC Donors ........................13

9. Sectoral Allocation of Technical Cooperation........................................................ 14

10. Composition of Aid Commitments to Sub-Saharan Africa ............................................16

11. Tied Status of Bilateral Commitments....................................................................... 17

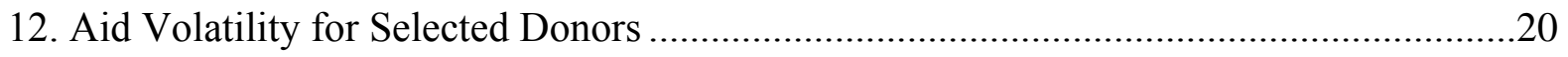

13. Volatility of Aid Excluding Debt Relief and Debt Relief as a Share of ODA .................21

Tables

1. Ranking of Bilateral Aid Effort, by Donor, 1991-95:ODA/GNP Versus EDA/GNP ..........8

2. Top Five Recipients of U.S. and Norwegian ODA, Ranked by Share ............................11

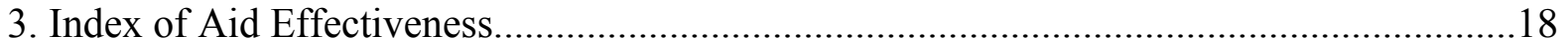




\section{INTRODUCTION}

What policies are needed to accelerate progress toward the halving of poverty by 2015 , as envisaged by the Millennium Development Goals (MDGs)? Recent high-profile reports counsel poor countries to implement sound policies that will boost and strengthen governance; they urge developed countries to enhance access to their markets for goods produced by poor countries and to increase the amount and effectiveness of the development assistance they offer (UN Millennium Project (2005), Commission for Africa (2005), World Bank-IMF (2005), and the UNDG, 2005). These reports view development assistance as being crucial, because poor countries are less likely to attract the private capital they need to build human capital and improve their productive and export capacities (OECD, 2005). ${ }^{2}$ This paper examines trends in development assistance since the 1960s and reviews proposals for making aid more effective. Its purpose is twofold: first, to examine changes among both aid donors and aid recipients over time; second, to trace trends in the composition of aid since the 1960s. Special attention is paid to aid flows since 2002, that is, following the Monterrey summit. ${ }^{3}$ The summit reiterated that developed countries should allocate 0.7 percent of their GNP for official development assistance (ODA) to developing countries, of which 0.15 to 0.20 percent of GNP should be earmarked for the least developed countries.

The remainder of this paper is organized as follows: Section II presents trends in aid and aid effort by major donors. Section III documents trends in aid by recipients. Section IV analyzes the composition of aid, particularly in the context of nationally owned development plans. Section V discusses the volatility of aid flows, and Section VI concludes.

\section{AID Flows, 1960-2004}

From the 1960s through the 1980s, aid flows (dollar-denominated volume flows at 2003 prices) grew at about 3 percent a year. ${ }^{4}$ In recent years, the growth rate of aid has picked up noticeably

\footnotetext{
${ }^{2}$ Development assistance (or official development assistance), which both bilateral and multilateral agencies disburse, comprises official grants or loans with a grant element of at least 25 percent. The concessionality of development assistance is measured by the difference between the present value of its interest rate and the market rate. By convention, the market rate is taken as 10 percent by the Development Assistance Committee (DAC) of the Organization for Economic Cooperation and Development (OECD). The grant element concept is not applied to the market-based lending of multilateral development banks. In addition to financial flows, technical cooperation is also included in aid. Grants, loans, and credits for the military are excluded, as are transfer payments to private individuals (for example, pensions, reparations, or insurance payouts). (See www.oecd.org for details.)

${ }^{3}$ In March 2002, the International Conference on Financing for Development was held in Monterrey, Mexico to address the shortfalls in the resources needed to achieve internationally agreed development goals, including the MDGs.

${ }^{4}$ The data are in U.S. dollars in constant prices and exchange rates.
} 
as some donors have responded positively to appeals made at the Monterrey summit. For example, in 2003, Belgium, Switzerland, the United Kingdom, and the United States increased their ODA by more than 10 percent, both in real terms and as a share of gross national income (GNI). In 2004, real ODA from all donors increased by 4.6 percent (OECD, 2005). These positive real increases represent a significant reversal from the late 1990s, when aid fell by 1 percent a year, on average. In absolute terms, the United States provides almost twice as much aid as the next highest donor (Japan). In fact, these two countries contribute about a third of total aid. However, the real dollar value of U.S. aid in recent years has, on average, been roughly the same as it was in the early 1960s (Figure 1). Since 2000, aid from European Union (EU) countries has amounted to approximately 50 percent of total ODA. The EU is currently considering proposals to make an additional EUR 20 billion a year in ODA available by 2010, rising to EUR 46 billion by 2015, with 50 percent of this increase directed at Africa (Commission of the European Communities, 2005).

Figure 1. Real Flows of Official Development Assistance, 1960-2004 (In millions of 2003 U.S. dollars)

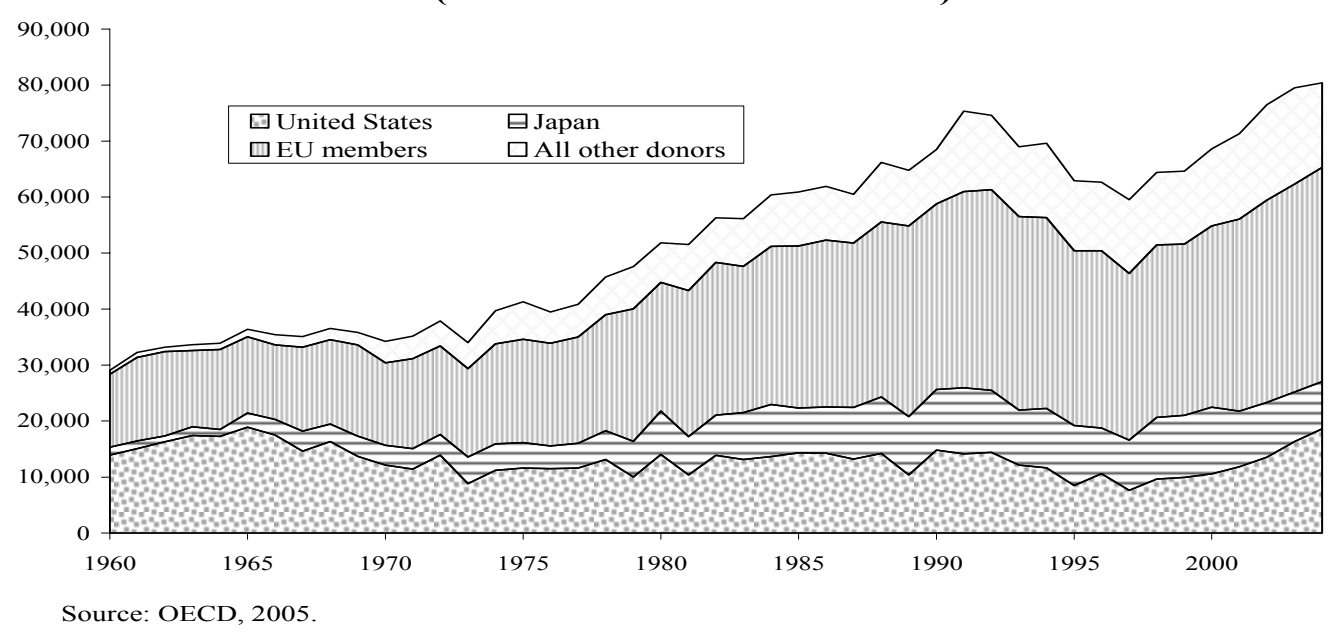

At 2003 prices, total ODA increased from about US\$30 billion in 1960 to almost US\$80 billion in 2004 . $^{5}$ However, the increase is not uniform across donors. The shares of France and the United States have fallen, while that of Japan has increased (Figure 2).

\footnotetext{
${ }^{5}$ In nominal terms, total aid in 2004 stood at US\$87 billion.
} 
Figure 2. Donor Share in Total Official Development Assistance (ODA)
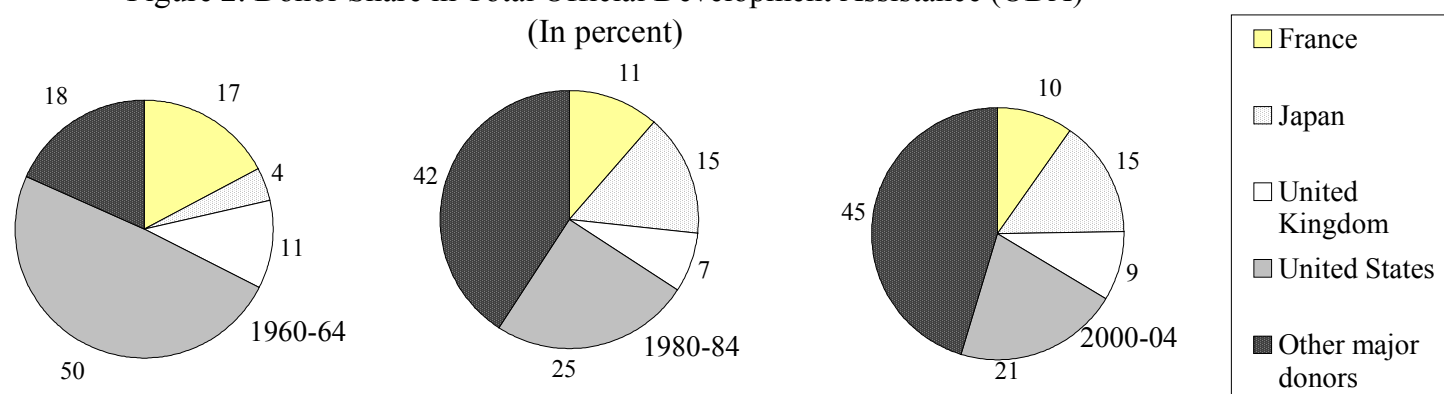

Source: OECD, 2005.

Only five countries (Denmark, Luxembourg, the Netherlands, Norway, and Sweden) have disbursed ODA equaling 0.7 percent or more of their GNI. The unweighted average of aid effort in 2004 was 0.42 percent of GNI, while the income-weighted average ODA/GNI ratio for DAC countries stood at 0.25 percent, suggesting that smaller donors are leading the aid effort. ${ }^{6}$ Among them, Norway ranked first with 0.87 percent of GNI, followed by Luxembourg with 0.85 percent of GNI. Italy and the United States ranked last with allocations of 0.15 percent and 0.16 percent, respectively (Figure 3). Over a longer time horizon, donors such as Australia, France, Germany, the United Kingdom, and the United States have seen declines in their ODA/GNI ratios.

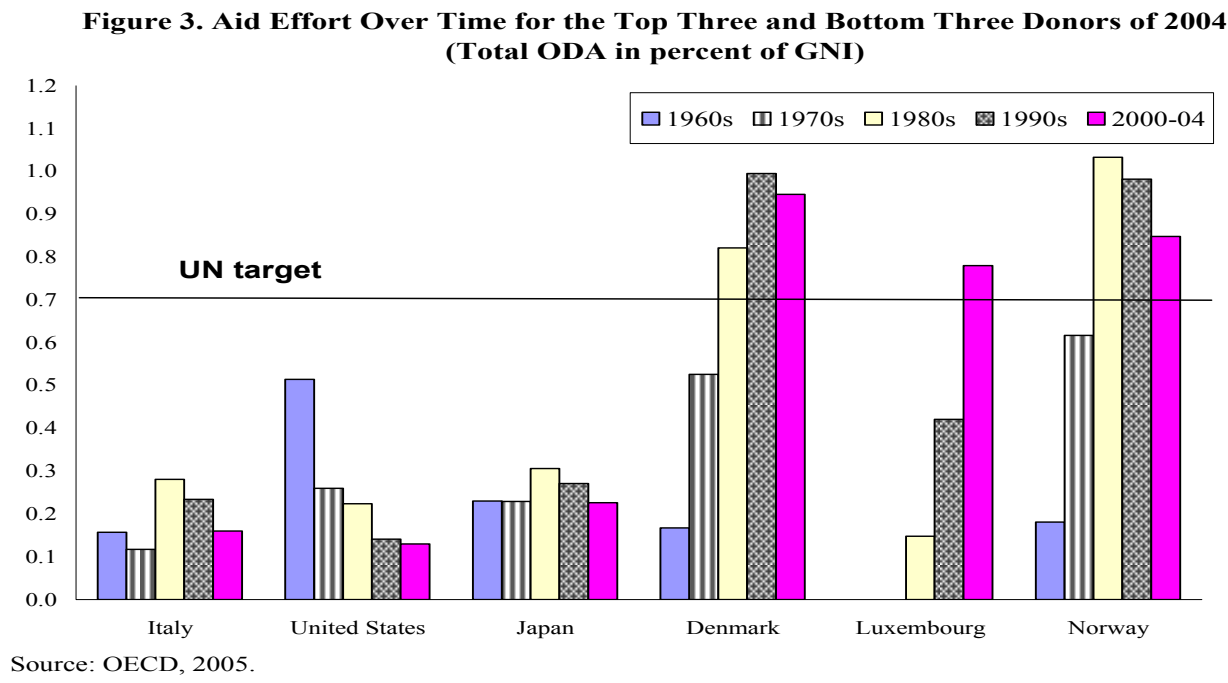

The major donors have different targets. Belgium has committed to meeting the UN target by 2010, Sweden has committed to 1 percent of GNI by 2006, Spain to 0.33 percent of GNI by 2006, and the United Kingdom to 0.47 percent of GNI by 2007-08 (OECD, 2005). In May 2005, the European Union (EU) announced that its members would double their aid to poor countries

\footnotetext{
${ }^{6}$ In the literature, aid effort refers to any measure that normalizes the volume of aid flows over some indicator of donor size, most often donor GNI or population.
} 
by 2015 , with about half of the new money going to Africa. The richest 15 member states agreed that by 2010 they would all be allocating at least 0.51 percent of national income to foreign aid, and that they would raise this share to 0.7 percent by 2015 . The 10 countries that joined the EU last year pledged to give 0.33 percent by 2015 . $^{7}$

The difference in donors' aid efforts can also be measured in terms of their populations (Figure 4). While the daily per capita allocation of aid from countries such as Denmark and Norway has increased since the 1960s, it has remained stable for the United States and Japan. In 2004, the United States allocated 17 cents a person a day to foreign assistance, the United Kingdom allocated 31 cents, France allocated 33 cents, Denmark allocated 92 cents, Norway US\$1.18, and Luxembourg US\$1.30. ${ }^{8}$

Figure 4. Per Capita Daily Aid from Selected Donors, 1960-2004

(In U.S. dollars)

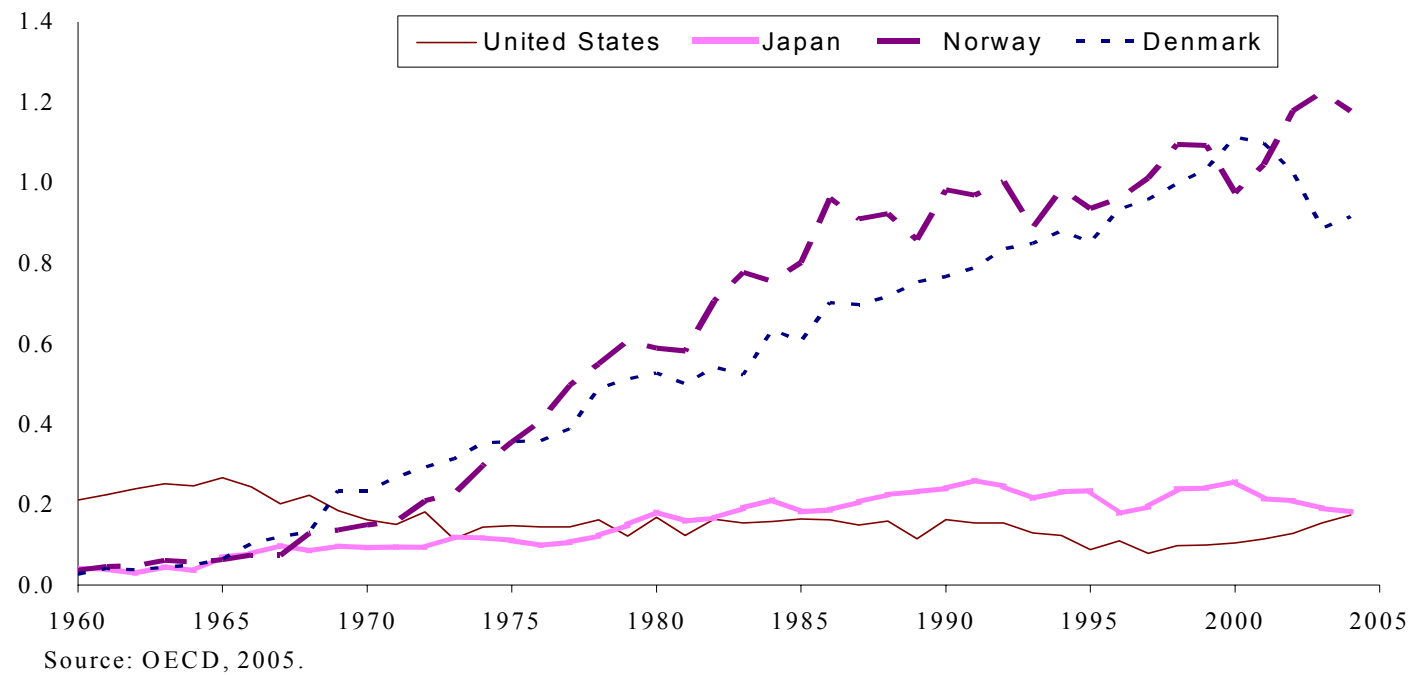

In addition to the total volume of aid, the degree of aid concessionality is also important for its effectiveness. Grants are increasingly being advocated because of growing concern with the debt problems of poor countries and the recognition that many types of aid (particularly in the social sectors) yield returns only in the long term. As a result, the share of grants in bilateral aid has been increasing over time (Figure 5). ${ }^{9}$ Since 2000, bilateral grants have grown, on average,

\footnotetext{
${ }^{7}$ Economist (2005). However, even if the recent commitments to scale up aid are met, aid would still be well below 0.7 percent of GNI in the immediate future. The most recent EU initiative commits member countries to an average ODA/GNI ratio of 0.56 percent by 2010 and a ratio of 0.7 percent only by 2015 (Commission of the European Communities, 2005).

${ }^{8}$ Data are not available for Germany and Italy for 2004.

${ }^{9}$ The main components of bilateral grants are (i) project aid; (ii) program assistance, that is, contributions for general development without sector allocation; (iii) technical cooperation, which includes both grants to nationals of aid-recipient countries receiving education or training at home or abroad, and payments to personnel such as
} 
by almost 7 percent a year, up from less than 2 percent a year in the 1990s. In volume, real bilateral grants increased from about US\$22 billion in 1960 to US\$59 billion in 2004. In the year following the Monterrey summit, the United States, for example, increased bilateral grants by over 40 percent in real terms.

\section{Figure 5. Bilateral Grants as a Share of Total ODA \\ (In percent)}

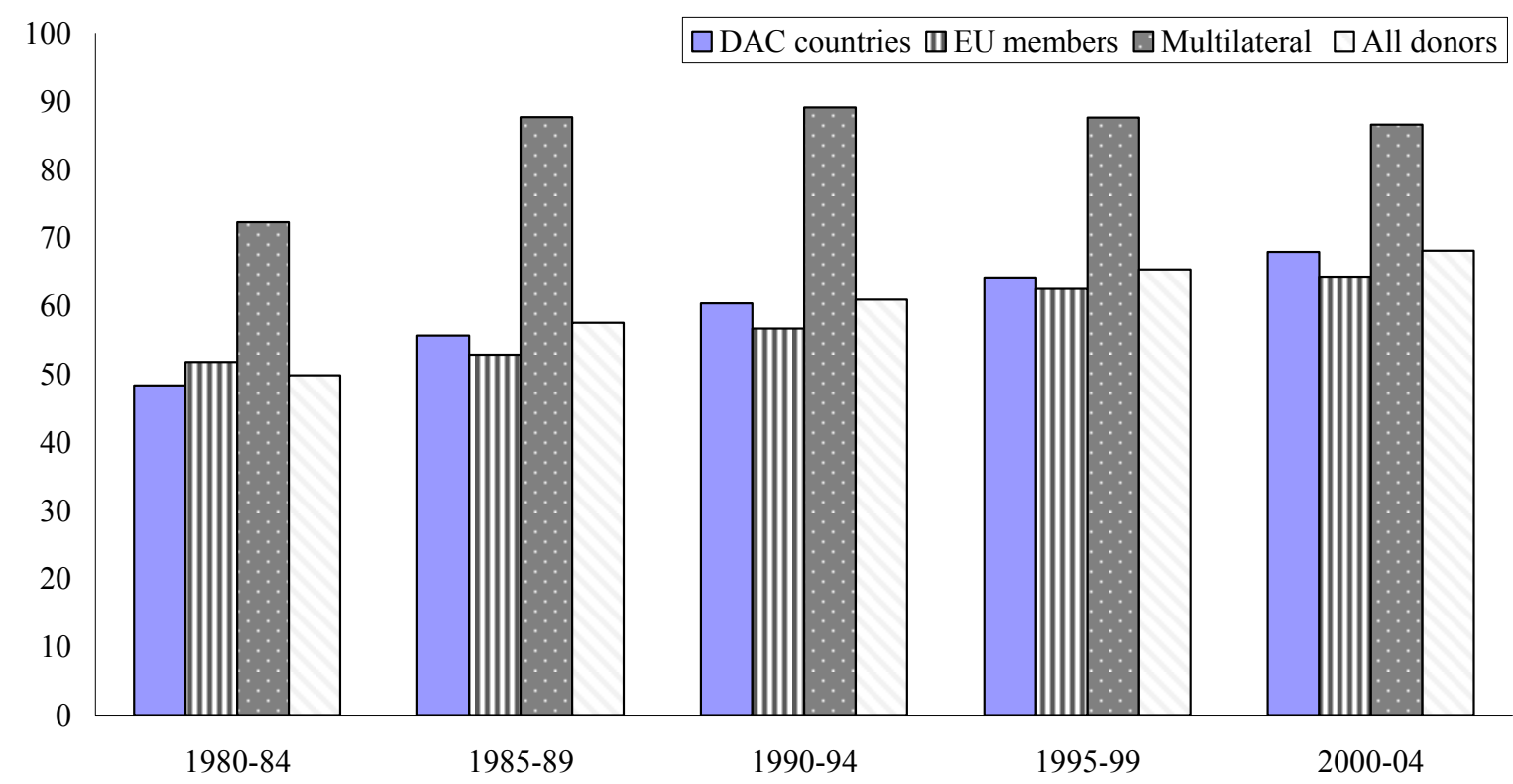

Source: OECD, 2005.

However, these estimates of nominal grants may overstate the true picture of resource transfers to poor countries. To better understand grant flows, Chang, Fernandez-Arias, and Serven (1998) estimate effective development assistance (EDA) as the aggregate of grant equivalents and grants, excluding technical cooperation. ${ }^{10}$ This adjusted measure includes only the grant equivalents of loans, rather than their full face value. This analysis reveals that donors such as France, Japan, and Spain rank higher on their ODA effort than on their EDA effort ${ }^{11}$ (Table 1).

consultants, advisers, teachers, and administrators serving in recipient countries (including the cost of associated equipment); (iv) developmental food aid; (v) emergency relief; and (vi) debt forgiveness.

${ }^{10}$ The OECD accounts for debt forgiveness by recording a grant matched with a loan repayment; since the World Bank's Debtor Reporting System used by the authors does not follow this practice, they exclude debt forgiveness from the grant totals used in their measure of net ODA and EDA.

11 The differences between ODA and EDA are surprisingly small. Moreover, it is likely that these differences would be even smaller if the EDA data were updated for the period after 1995, since donors have moved increasingly into grants. 
Table 1. Ranking of Bilateral Aid Effort, by Donor, 1991-95:

ODA/GNP Versus EDA/GNP

(In percent)

\begin{tabular}{lclc}
\hline & ODA/GNP & & EDA/GNP \\
Norway & 0.39 & Norway & 0.38 \\
Sweden & 0.32 & Denmark & 0.33 \\
Denmark & 0.32 & Sweden & 0.31 \\
France & 0.24 & Finland & 0.22 \\
Finland & 0.24 & Netherlands & 0.22 \\
Austria & 0.21 & France & 0.20 \\
Netherlands & 0.19 & Austria & 0.19 \\
Australia & 0.18 & Australia & 0.16 \\
Japan & 0.16 & Switzerland & 0.15 \\
Switzerland & 0.15 & Germany & 0.14 \\
Germany & 0.15 & Canada & 0.13 \\
Canada & 0.13 & Belgium & 0.12 \\
Belgium & 0.12 & Luxembourg & 0.12 \\
Luxembourg & 0.12 & Japan & 0.08 \\
Italy & 0.10 & Italy & 0.08 \\
& & United & \\
Spain & 0.09 & Kingdom & 0.07 \\
United & & & \\
Kingdom & 0.07 & United States & 0.07 \\
United States & 0.07 & Spain & 0.05 \\
Portugal & 0.04 & Portugal & 0.04 \\
New Zealand & 0.04 & New Zealand & 0.04 \\
\hline & & &
\end{tabular}

Source: Chang, Fernandez-Arias, and Serven (1998).

Notes: Since the net ODA flows reported here include only bilateral flows and exclude technical cooperation and debt forgiveness, they do not necessarily match the flows used in the calculations for Appendix Table 1. EDA denotes effective development assistance.

Private philanthropy and worker remittances have come to play an increasingly important role in the transfer of resources to poor countries. However, views of what part of private giving qualifies as development assistance vary widely. Adelman (2003) estimates that private giving, which in her definition includes worker remittances, from the United States amounts to as much as three and a half times its ODA. ${ }^{12}$ Her estimates imply that private international giving from the United States in 2003 amounted to approximately US\$56 billion, or an additional

\footnotetext{
${ }^{12} \mathrm{IMF}(2005)$ estimates that worker remittances have increased fivefold since the 1980 s, to stand at US\$91 billion in 2003. This figure is significantly higher than total official flows and private flows that are not foreign direct investment to poor countries. Moreover, since some portion of remittances is sent through informal channels, the figure most likely underestimates the actual transfer of resources. However, the inclusion of worker remittances in private development assistance can be questioned.
} 
0.5 percent of its GNI, bringing its aid effort to 0.65 percent of GNI (IMF, 2005). ${ }^{13}$ In contrast, Roodman (2004) estimates that total U.S. contributions through church groups, the Red Cross, and other charities add up to just another 6 cents a day per capita. This would imply that private international giving from the United States amounted to about US\$6.5 billion, or an additional effort of 0.05 percent of GNI, raising the total effort to 0.2 percent.

Only a small share of private American philanthropy goes to international charities (Micklewright and Wright, 2005). In contrast, about three-fourths of total German donations to the top 16 charities went to development charities, while in the United Kingdom the share of development assistance in total charity contributions was about one-fourth, and, in the Netherlands, it was about 15 percent. They estimate that private development assistance from OECD countries in 2001 totaled US\$17 billion, compared with total ODA of US\$52 billion that year (Atkinson, 2005). ${ }^{14}$

\section{Aid Flows BY Destination AND Donor TARgeting}

Does aid reach those who are most in need? Studies indicate that factors other than economic necessity or effective use of aid play a role in determining the volume of aid a country receives (Alesina and Dollar, 1998). It has also been suggested that different donors are motivated by different considerations when disbursing aid (Gates and Hoeffler, 2004). Generally, this debate distinguishes between donors motivated by past colonial ties, by current foreign policy considerations, and by recipient need. However, MacGillivray (2003a, 2003b) posits that much of this literature inappropriately separates "donor interest" and "recipient need" models. And, he says, once this dichotomous treatment is resolved, there is evidence that even before the end of the cold war, developmental considerations had a much greater impact on aid allocation than is generally believed.

Changes over time in aid shares by regional destination are likely to reflect evolving donor motivations, as well as the changing needs of poor countries in different regions. Sub-Saharan Africa, the largest regional recipient of aid in 2003, received almost 30 percent of total ODA (Figure 6). ${ }^{15,16}$ For the region, this represents a substantial increase over the 13 percent share it

\footnotetext{
${ }^{13}$ IMF (2005) estimates that, in 2003, the outflow of remittances from the United States amounted to US\$34 billion.

14 There have also been attempts to explore new sources of development finance. Proposals range from international taxes on currency transactions (more commonly known as the Tobin tax), and a tax on airline fuel to a global lottery. One such proposal has received some attention. The International Finance Facility proposed by the United Kingdom would allow borrowing in international capital markets against long-term aid commitments by donors (Atkinson, 2005).
}

${ }^{15}$ The small discrepancy between the total aid numbers in Figure 1 and Figure 6 can be explained by the exclusion of multilateral recipients in the latter. 
received in 1960. From the early 1960s to the 1980s, more than 40 percent of ODA was directed toward Asia. By 2003, Asia's share had fallen to one-fourth of total ODA. In the same year, South America received 4 percent of total aid, and the Middle East accounted for about 7 percent of total aid, of which Iraq received 3 percent. Among individual countries, the Democratic Republic of Congo (DRC) and Iraq received the largest share of ODA in 2003. Whereas Iraq's allocation is mostly intended for postconflict capacity building, a substantial portion of the DRC's allocation takes the form of debt forgiveness.

Figure 6. Real Flows of Aid by Recipient, 1960-2003

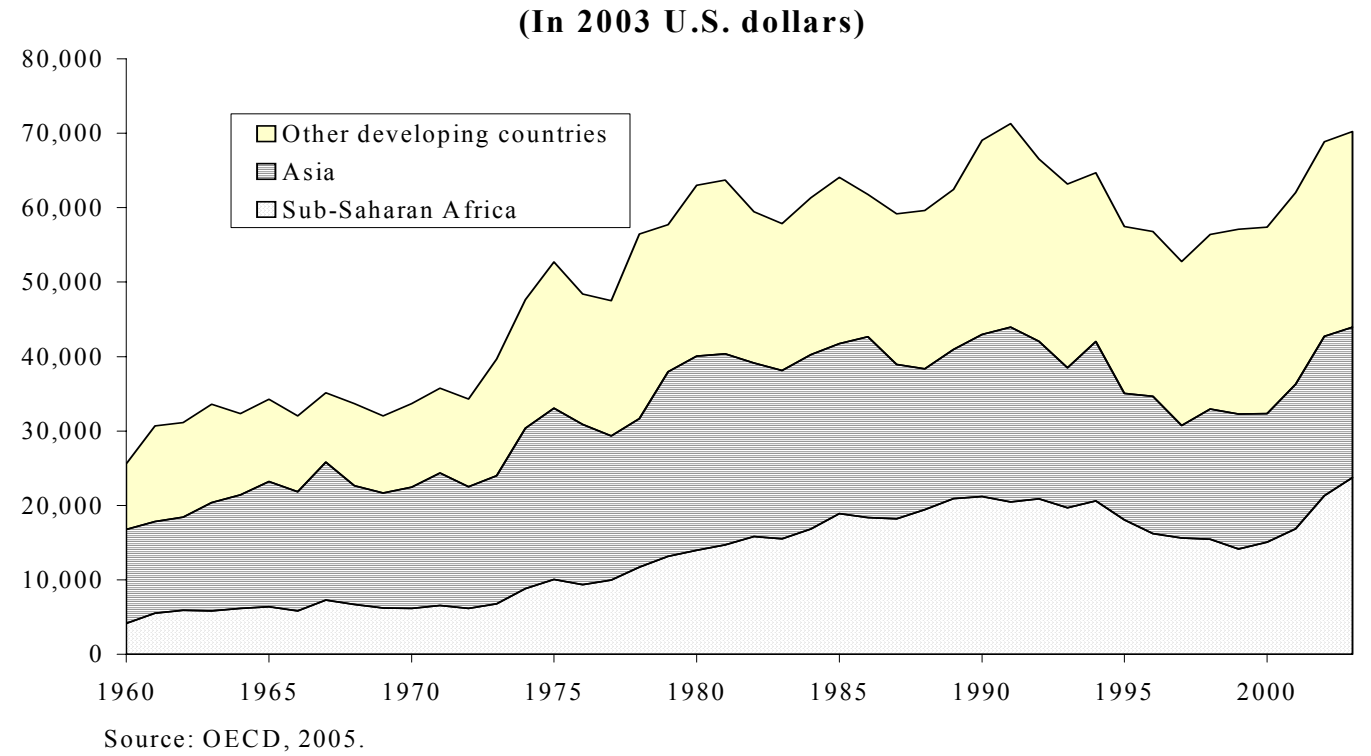

Until the 1980s, countries in North Africa, especially Algeria, were the most significant recipients of aid outside Asia and sub-Saharan Africa. Since the 1990s, the newly independent states of East and Central Europe have emerged as significant recipients. India accounted for about 10 percent of ODA in the mid-1970s; since then, its share has fallen gradually to about 2 percent in the new millennium.

Aid flows are driven by multiple considerations (Table 2). On average, Israel has received the largest share of U.S. ODA since 1960. Over the same period, the most important recipient of Norwegian aid has been Tanzania, with an average share of 5.7 percent, followed by India with an average share of 5 percent. In 2003, only 4 of the top 10 recipients of U.S. aid were poor countries, and the top 5 accounted for almost 32 percent of total assistance from the United

\footnotetext{
16 This contrasts with the analysis in McGillivary and Sefuke (2004) in which a decline in aid to sub-Saharan Africa is noted during 1960-2002 period.
} 
States. ${ }^{17}$ In contrast, 7 of the top recipients of Norwegian aid in 2003 were poor countries, but the top 5 recipients accounted for less than 15 percent of total assistance from Norway.

Table 2. Top Five Recipients of U.S. and Norwegian ODA, Ranked by Share

\begin{tabular}{|c|c|c|c|}
\hline \multicolumn{2}{|c|}{ Recipients of U.S. Assistance } & \multicolumn{2}{|c|}{ Recipients of Norwegian Assistance } \\
\hline \multicolumn{4}{|c|}{ Average share over 1960-2003 } \\
\hline Israel & 9.1 & Tanzania & 5.7 \\
\hline Egypt & 7.5 & India & 5.0 \\
\hline India & 5.6 & Bangladesh & 3.9 \\
\hline Vietnam & 4.7 & Mozambique & 3.6 \\
\hline Pakistan & 3.2 & Kenya & 3.0 \\
\hline \multicolumn{4}{|c|}{ Average share over $2000-03$} \\
\hline Egypt & 5.2 & Serbia and Montenegro & 2.9 \\
\hline Iraq & 4.8 & Tanzania & 2.9 \\
\hline Jordan & 2.8 & Afghanistan, I.S. of & 2.7 \\
\hline Colombia & 2.5 & Palestinian adm.areas & 2.7 \\
\hline Pakistan & 2.5 & Mozambique & 2.6 \\
\hline \multicolumn{4}{|l|}{ Share in 2003} \\
\hline Iraq & 9.5 & Afghanistan, I.S. of & 3.4 \\
\hline Congo, Dem. Rep. of & 8.7 & Tanzania & 3.3 \\
\hline Jordan & 5.8 & Iraq & 2.9 \\
\hline Colombia & 4.1 & Mozambique & 2.6 \\
\hline Ethiopia & 3.5 & Palestinian adm.areas & 2.6 \\
\hline
\end{tabular}

Source: OECD, 2005

\section{Composition OF Aid Flows AND NATional OWNership of DEVElopment STRATEGIES}

National leadership and ownership of development plans are seen as critical for enhancing aid effectiveness. Much of the literature on aid effectiveness has focused on analyzing what conditions or type of environment is needed in the recipient country so that aid has the most beneficial impact. According to Burnside and Dollar (2000), a good policy environment makes a significant difference in how effectively a country uses aid. Despite subsequent questions

${ }^{17}$ The Millennium Challenge Account established in 2004 directs U.S. aid to poor countries that practice good governance and sound policies and that invest in their people. Aid eligibility is linked to countries' rankings on the basis of several criteria, like political rights, primary education expenditures, trade policy, and inflation. On March 14, 2005, the first compact between the United States and Madagascar was approved, with an aid allocation of $\$ 110$ million over four years. 
about their results (Easterly, Levine and Roodman, 2004), donors seem likely to favor countries with a strong commitment to development, and recent evidence by Dollar and Levin (2004) supports this view. In a similar vein, Radelet (2004) relates aid effectiveness to the quality of governance in the recipient country.

In contrast, studies that examine the connection between the composition of aid and its effectiveness are relatively scarce. Clemens, Radelet, and Bhavnani (2004) contend that different types of aid have differential effects on growth. They find that "short impact" aid flows, such as budget and balance of payments support, and investment in economic infrastructure have a much greater impact on growth than does aggregate aid.

Over time, the composition of aid has changed. One less well known feature of this changing composition is that technical cooperation has been increasing both in real terms and as a share of total ODA since the 1960s (Figure 7). In recent years, donors have provided roughly onefourth of their ODA in the form of technical cooperation. In 2004, Australia, Greece, and the United States disbursed 50 percent or more of their ODA in this form, although less than 10 percent of the ODA of the top four donors (ranked by aid effort) took the form of technical cooperation. In the same year, real aid flows increased by US\$3.1 billion, and technical cooperation grants rose by US $\$ 1.2$ billion; that is, almost 40 percent of the additional aid dollars available were in the form of technical cooperation.(OECD, 2005). Since 2000, overall ODA has grown at about 5 percent a year, whereas real technical cooperation has grown at about 14 percent. In contrast, the share of food aid has declined to about 2 percent of ODA since 2000.

Figure 7. Composition of Aid (In percent of total ODA)
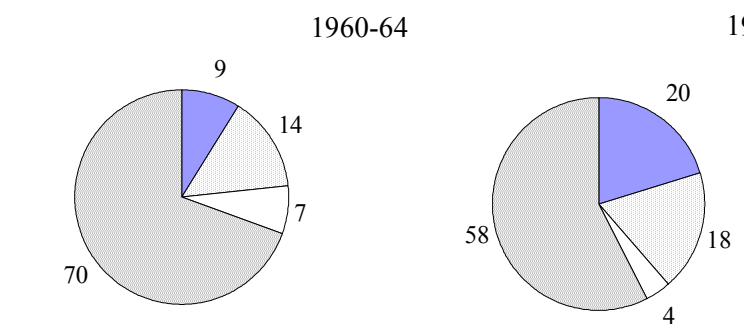

$1980-84$

Source: OECD, 2005.

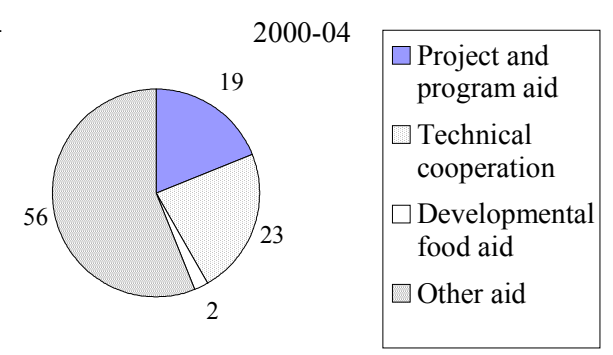

\section{A. Technical Cooperation}

Since the early 1990 s, the effectiveness of technical cooperation has come under considerable scrutiny. As Berg (1993, p. 244) points out, "almost everyone acknowledges the ineffectiveness of technical cooperation in what is or should be its major objective: achievement of greater self-reliance in the recipient countries." In general, the perception is that technical cooperation is a form of assistance largely controlled by the donors, not least because it tends to generate considerable economic benefits for the consulting industry in the donor country. Additionally, donors frequently come under political pressure from their own parliaments and governments 
to advocate areas for assistance that might have low priority in a recipient country (Ajayi and Jerome, 2002).

Donor-funded institutional capacity building is seen as particularly ineffective, whereas engineering or "hard" technical cooperation is generally considered more effective. Much of the criticism of technical cooperation earmarked for institutional capacity building is directed at accountability arrangements. In a bid to make technical cooperation more result-oriented, donors favor a very short production-oriented planning horizon (Hauge, 2002). These arrangements afford recipients little control over the planning, implementation, or monitoring of the process.

The government budget is a vehicle for establishing clearly designated spending priorities. The bulk of technical cooperation funds, however, is rarely reported in the budgets of recipient governments. Rather, most technical cooperation is provided in kind and takes the form of personnel or administrative costs accruing to donor-appointed agents. This form of aid is generally believed to be the least coordinated among the donors. Even when technical cooperation does involve highly skilled personnel from the country receiving the aid, it is criticized for creating a small elite group of individuals who benefit from better pay and better work conditions - a practice that demoralizes the local civil service. A large share of technical cooperation is allocated to personnel expenditures. In 2003, for example, technical cooperation personnel costs made up about 40 percent of total technical cooperation. In contrast, the combined spending on students, trainees, and equipment added up to less than 40 percent of the total (Figure 8).

Figure 8. Composition of Technical Cooperation

Expenditures from DAC Donors

(In percent of total)

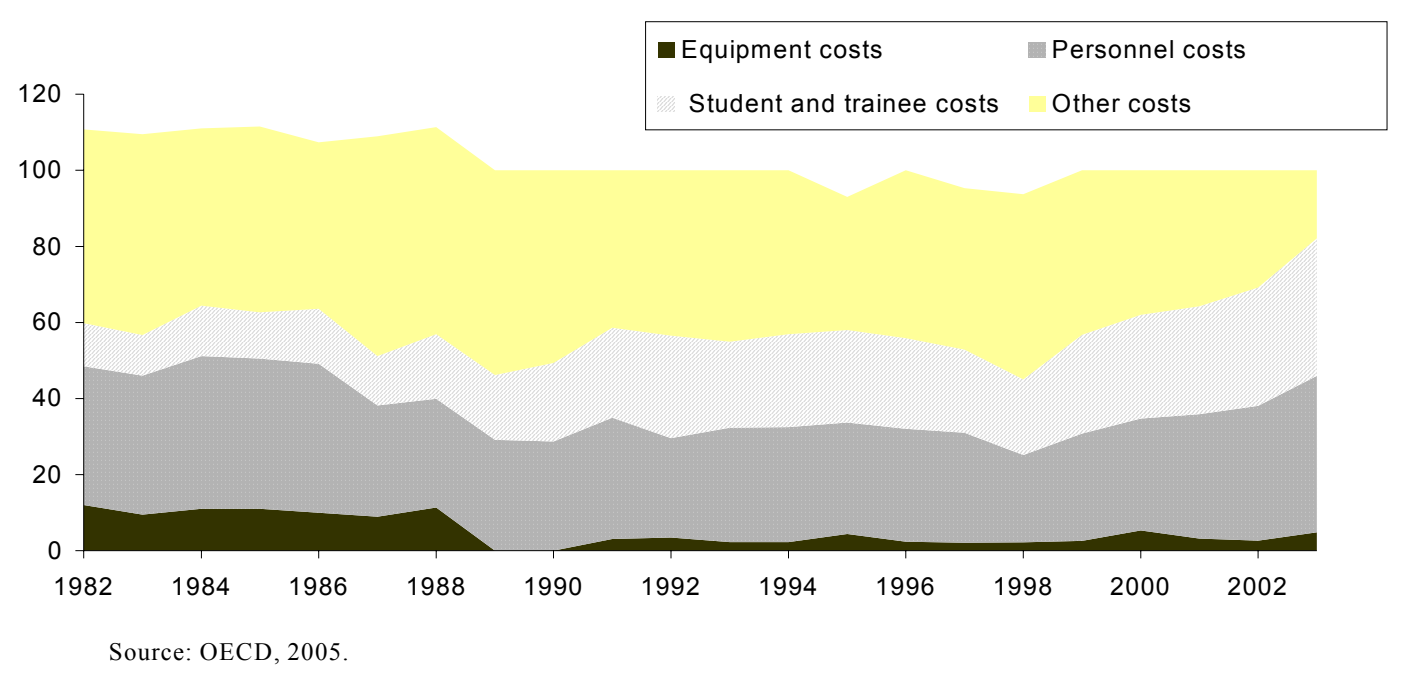


A disaggregation of technical cooperation by sector shows that allocations to social infrastructure have increased since the 1990s, whereas those to economic infrastructure, agriculture, and industry have declined slightly (Figure 9). Almost 70 percent of the technical cooperation going to sub-Saharan Africa since 2000 has been allocated to social infrastructure, including education and health, a significant rise from the 55 percent allocated to this sector in the 1990s. At the same time, the combined share of economic infrastructure, agriculture, and industry has fallen from 25 percent to 16 percent. The increase in the share of social infrastructure has also occurred in South America, but the subcomponents differ in the two regions: the share of education and health has remained roughly the same in sub-Saharan Africa but has fallen in South America. And while the share of government and civil society has increased from 20 percent to 30 percent in sub-Saharan Africa, it has doubled from 23 percent to 50 percent in South America. Thus, technical cooperation is particularly poorly allocated in South America - the region receiving the largest share of its ODA as technical cooperation. The shares of education and health have also fallen in the Middle East and South and Central Asia, whereas the share of total social infrastructure has gone up. ${ }^{18}$ The combined share of economic infrastructure, agriculture, and industry has also fallen in these regions. A higher share of technical cooperation is allocated to economic infrastructure in South and Central Asia than in other regions.

\section{Figure 9. Sectoral Allocation of Technical Cooperation (In percent of total)}

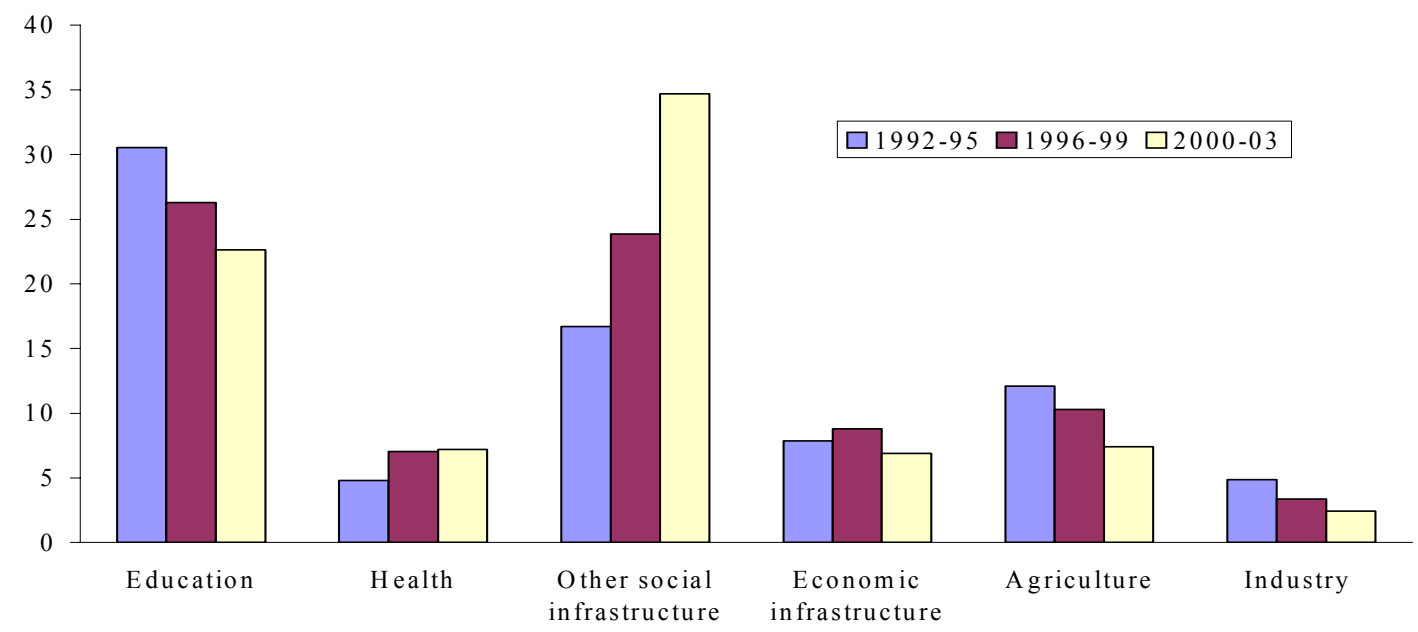

Source: OECD, 2005 .

\footnotetext{
${ }^{18}$ Social infrastructure comprises programs for government and civil society, population, employment, and housing, as well as education and health.
} 


\section{B. Budget Support and Program Assistance Versus Project Aid}

The allocation of aid between budget support, program assistance, and sector-specific project aid also influences the ability of recipient country governments to fund national priorities. ${ }^{19}$ Additionally, the discussion on aid fungibility makes a case for aid in the form of non-sectorspecific program assistance (Devarajan and Swaroop, 1998). In countries with well-designed public spending programs. Donors generally prefer to provide a greater share of aid as budget support. Budget support affords the recipient countries the flexibility to align their aid spending with national priorities and is more effective when their governments have good policies (Cordella and Dell'Ariccia, 2003). Eifert and Gelb (2005) favor budget support regardless of governance levels in recipient countries, so that donors can avoid the high transaction costs of implementing multiple projects. They argue that the current selectivity in the allocation of aid between project aid and budget support might underestimate the role of the latter as an investment in countries' public expenditure management systems. They recommend stable budget support commitments for several years with the caveat that donors can respond sharply to a catastrophic change in macro management. However, project aid that is used to finance imports does not have any effect on the real exchange rate and thus mitigates potential Dutch disease effects of aid (Adam, 2005). ${ }^{20}$ Project aid is also less volatile than aid given as general budget support.

Since 2000, donor countries have steadily increased their commitments of budget support, from about 10 percent to about 20 percent of total aid commitments (Bulir and Hamann, 2005). ${ }^{21}$ In contrast, the share of project aid declined from 68 percent in 2000 to 61 percent of total commitments in 2003. The increased share of budget support mostly reflects increased commitments to debt forgiveness. Since 1995, about 70 percent, on average of all donor budget support commitments have been in the form of debt relief. To the extent that debt forgiveness represents a write-off of the face value of concessional debt, each dollar of debt forgiveness does not necessarily represent a one-to-one outward shift in the recipient country's budget constraint.

Has increasing debt relief been associated with reductions in other types of aid? This is a large issue, which we touch on only lightly here. Since 2000, France, Germany, and the United

\footnotetext{
${ }^{19}$ We define budget support as non-sector allocable assistance whose provision is explicitly linked to agreed policy packages, in particular those implementing recommendations made by the World Bank and the IMF and all actions relating to debt forgiveness, swaps, buybacks, rescheduling, and refinancing. Program assistance is budget support plus commodity assistance, but excludes debt forgiveness. All sector-specific aid is designated as project aid.

${ }^{20}$ Please refer to Bulir and Lane (2002); Prati, Sahay, and Tressel (2003); and Rajan and Subramanian (2004) for details on the impact of aid flows on real exchange rates and the tradables sector.

${ }^{21}$ Because net disbursement series are unavailable, aid commitment data are used in this section. Bulir and Hamann (2005) estimate that, on average, aid delivery falls short of promises by more than 40 percent.
} 
Kingdom have shown a negative correlation between the rate of increase in their project aid commitments and that of their debt-forgiveness commitments. However, other donors, such as Belgium, Italy, and Portugal — which also committed to providing debt relief-have exhibited no such offsetting adjustments of their project aid commitments. ${ }^{22}$

Debt forgiveness has accounted for a large share of the commitments made to sub-Saharan Africa since the launch of the Enhanced Heavily Indebted Poor Countries (HIPC) Initiative (Figure 10). Although in absolute terms, program assistance (including commodity aid) and project aid have increased, their shares in total aid commitments to the region have declined. In South America, where the share of debt forgiveness in bilateral commitments fell between 1994-99 and 2000-04, the share of project aid in bilateral commitments has simultaneously risen. However, a simple analysis indicates that, although there was a negative correlation between debt relief and aid excluding debt relief during 1995-99, this statistic is positive for the 2000-03 period. That is, while components of aid other than debt relief may not have grown as rapidly as total aid, there appears to be no evidence that they been crowded out by debt relief in the new millennium.

Figure 10. Composition of Aid Commitments to Sub-Saharan Africa (In percent of total bilateral commitments)

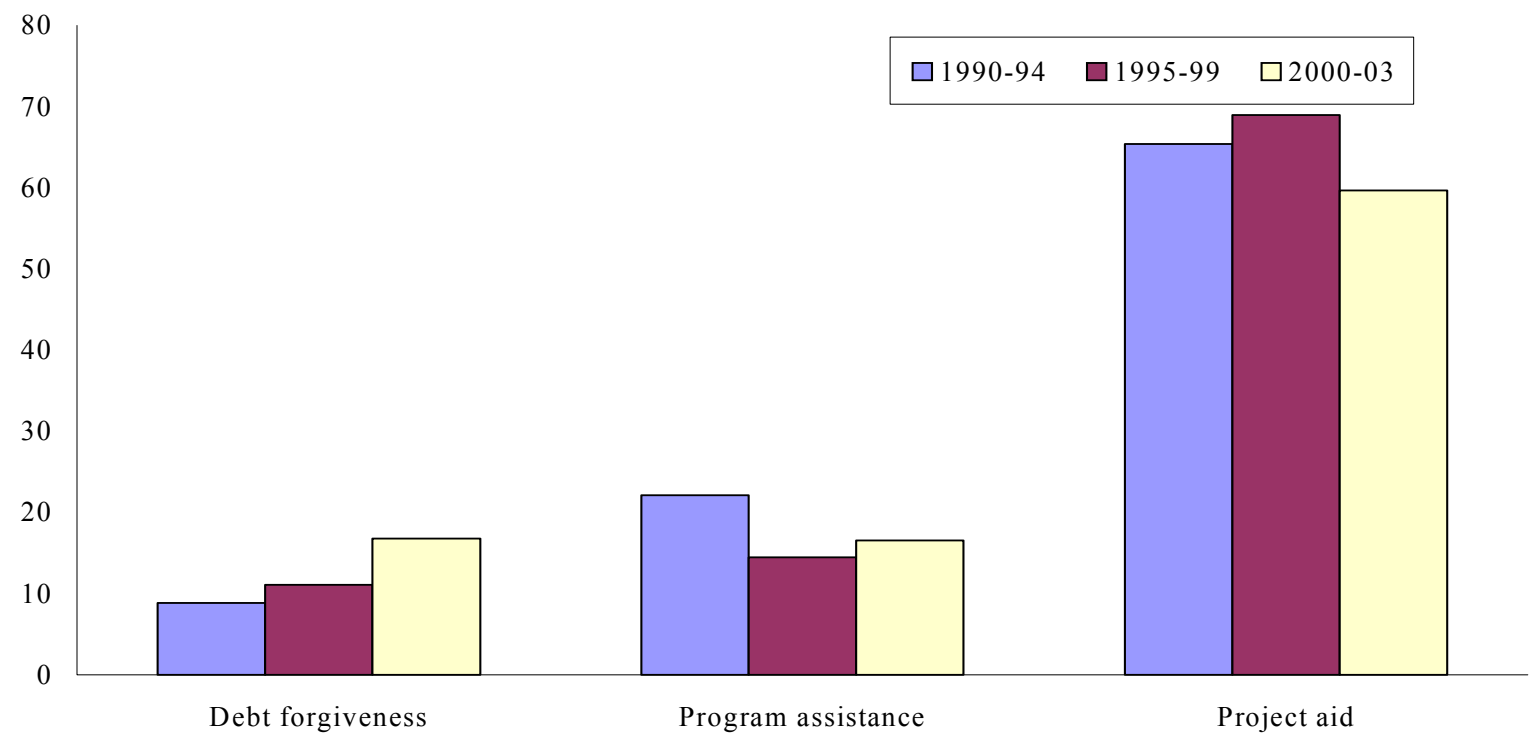

Source: OECD, 2005.

While budget support is significantly more flexible than project aid, tied aid is the least flexible. ${ }^{23}$ Untied aid is ODA for which the associated goods and services may be fully and

\footnotetext{
${ }^{22}$ This idea is further explored in the section on aid volatility.

23 See also McGillivray and Sefuke (2004).
} 
freely procured in all countries, whereas tied aid refers to official loans, credits, or associated financing packages for which the procurement of the goods or services involved is restricted to the donor country or to a group of countries. The extent to which aid is tied also affects the ability of recipient governments to use aid effectively and in line with national priorities. The share of tied aid has fallen quite dramatically over the past twenty years (Figure 11). ${ }^{24}$ The paucity of donor-specific data makes detailed comparisons difficult, but the data indicate that donors such as Denmark, the Netherlands, and Sweden were tying less than 25 percent of their aid even in the 1980s.

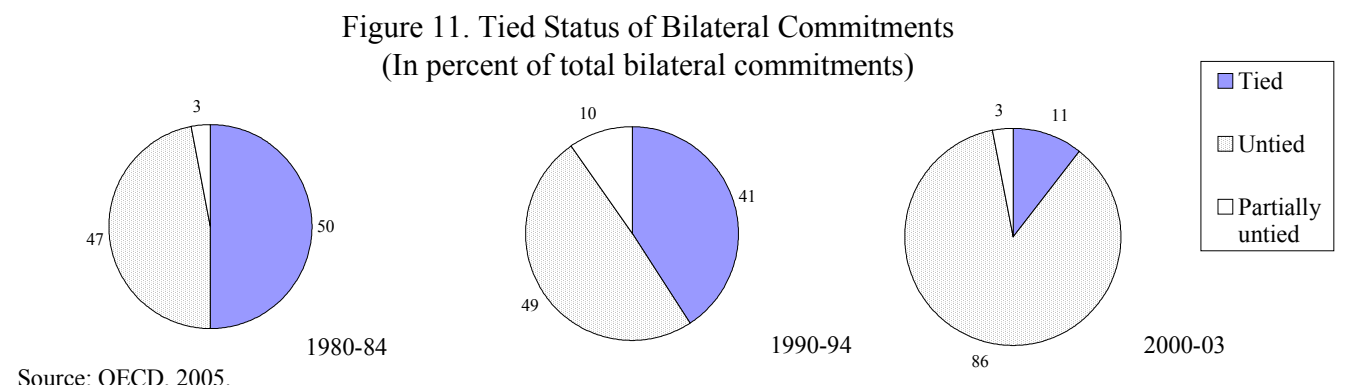

How do countries stack up if adjustments are made to raw aid numbers to estimate how effective the aid has been? Such estimates exist for three years, 2003, 2004 and 2005 (Table 3). The Netherlands and the Scandinavian countries take the top four slots for all three years, and the United States, and Italy are in the bottom three countries. The United States loses in part because of its tying of aid, while Denmark gains in part by aiding relatively big projects in poor countries.

${ }^{24}$ The chart is also based on bilateral commitment data. 
Table 3. Index of Aid Effectiveness ${ }^{1}$

\begin{tabular}{lrlrlr}
\hline Donor Country & 2003 & Donor Country & 2004 & Donor Country & 2005 \\
\hline United States & 1.7 & Italy & 1.6 & Japan & \\
Italy & 2.2 & New Zealand & 2.0 & Italy & 1.4 \\
Greece & 2.3 & United States & 2.1 & United States & 1.6 \\
Canada & 2.4 & Greece & 2.5 & New Zealand & 1.9 \\
New Zealand & 2.8 & Austria & 2.7 & Australia & 2.1 \\
Portugal & 2.8 & Canada & 2.9 & Spain & 2.5 \\
Australia & 2.9 & Japan & 2.9 & Greece & 2.6 \\
Japan & 3.0 & Germany & 3.0 & Portugal & 2.8 \\
Spain & 3.2 & Spain & 3.1 & Canada & 2.8 \\
Germany & 3.6 & Australia & 3.1 & Austria & 2.9 \\
Austria & 3.8 & Portugal & 3.5 & Germany & 3.0 \\
France & 4.3 & United Kingdom & 4.3 & France & 3.4 \\
Finland & 4.6 & France & 4.4 & Finland & 4.1 \\
United Kingdom & 5.0 & Finland & 5.1 & Belgium & 4.9 \\
Ireland & 5.5 & Switzerland & 5.3 & United Kingdom & 5.4 \\
Switzerland & 5.8 & Ireland & 5.4 & Ireland & 5.6 \\
Belgium & 5.9 & Belgium & 5.5 & Switzerland & 5.6 \\
Norway & 8.8 & Netherlands & 8.9 & Netherlands & 6.0 \\
Sweden & 9.5 & Norway & 10.3 & Sweden & 8.7 \\
Netherlands & 10.0 & Sweden & 12.0 & Norway & 9.8 \\
Denmark & 14.8 & Denmark & 14.3 & Denmark & 10.8 \\
\hline
\end{tabular}

Source: Center for Global Development (http://www.cgdev.org).

${ }^{1}$ The index penalizes "tied" aid; subtracts debt repayments by poor countries to rich; favors aid to countries with high poverty and relatively good governance; penalizes donors for overloading recipient governments; and rewards governments that allow taxpayers to write-off charitable contributions.

\section{Aid Volatility and Predictability of Development Financing}

Resource flows to developing countries must be predictable to enable the countries to formulate and implement long-term poverty-reduction strategies. ${ }^{25}$ Studies have shown that aid tends to be

\footnotetext{
${ }^{25}$ The recent U.K. initiative to establish the International Financing Facility (IFF) would reduce the annual volatility of aid disbursements. However, budgetary constraints among major donors, especially those relating to the European Union's Growth and Stability Pact, remain a concern.
} 
procyclical and more volatile than GDP or fiscal revenues in developing countries (Pallage and Robe, 2001; Bulir and Hamman, 2005). Furthermore, the estimated output and welfare losses associated with aid volatility are quite severe (Lensink and Morrisey, 2000; Pallage and Robe, 2003). Gupta, Clements, and Tiongson (2004) find that food aid has been countercyclical only for countries with the greatest need but not for most countries and is insufficient to mitigate consumption shortfalls. Eifert and Gelb (2005) elaborate the dangers of unpredictable budget support. If nonemergency assistance pledges are highly volatile, recipients are likely to heavily discount aid commitments in their medium-term budgeting and to reduce planned expenditures. Donors, seeing few funding gaps, are likely to lower future aid pledges.

Since 1995, the volatility of aid flows relative to recipient country fiscal revenues has increased sharply (Bulir and Hamann, 2005). We analyze this issue from the perspective of donor disbursements rather than from the perspective of aid recipients. Using the detrended, real national currency aid allocation series (normalized over the donor-specific, full-period average), we calculate the standard deviation for major donors. ${ }^{26}$ In line with the Bulir and Hamann results, we find that there has been an increase in overall donor volatility since 1995 . The median coefficient of variation for major donors - which is relatively stable after 1970 shows an increase between 1995 and 1999 and then another sharp increase between 2000 and 2003 (Figure 12). In most cases, the volatility of aid from a specific donor tends to fluctuate around the median. However, aid flows from Denmark and Norway are less volatile than the median, while aid flows from Italy and the United States have been more volatile than the median. Since the 1990s, however, the volatility of U.S. aid has declined.

\footnotetext{
${ }^{26}$ Following Bulir and Hamman (2005), we set lambda at 7 . The volatility of the cyclical component of the log transformation of real flows of aid reveals a very similar pattern.
} 
Figure 12. Aid Volatility for Selected Donors (Standard deviation in percent)

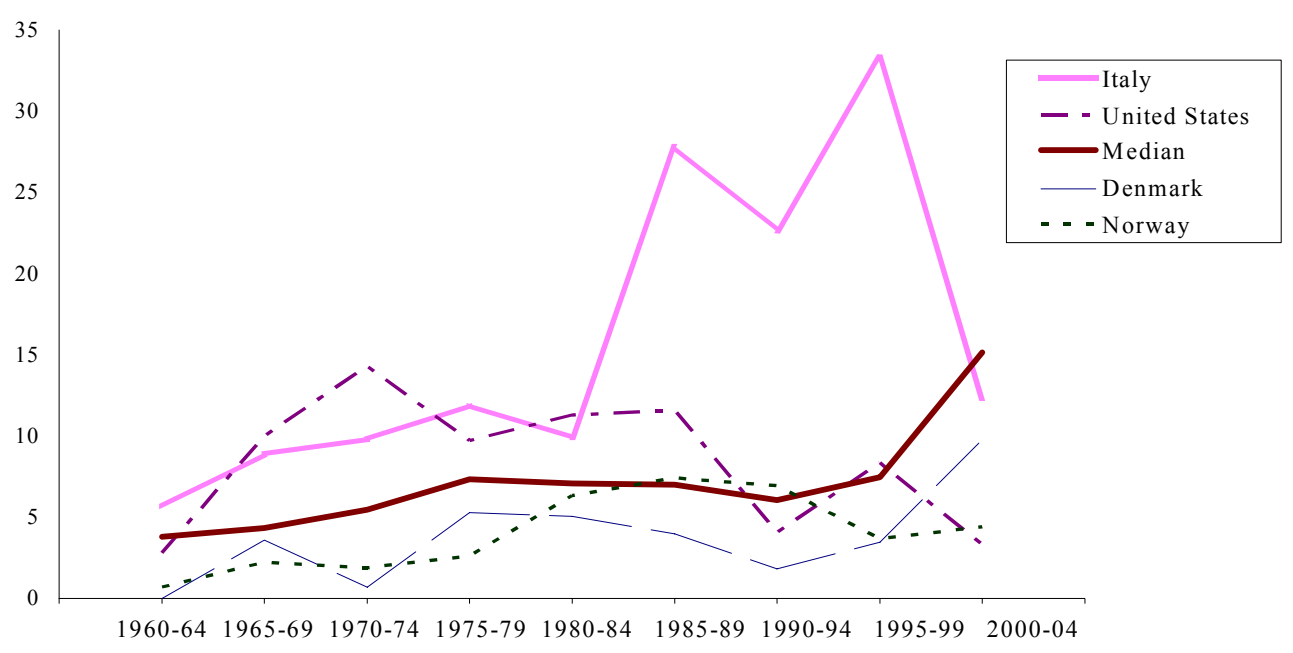

Sources: OECD, 2005; IMF staff calculations.

Some part of the higher volatility in recent years can be attributed to the forgiveness of countries' debt, which, as one-off events, is inherently volatile. However, volatility remains high even when debt relief is excluded from aid flows, implying that development assistance excluding debt relief has become more volatile in the new millennium. The higher volatility is especially apparent among donors who have played a prominent role in writing off debt (Figure 13). Between 2000 and 2003, the correlation between the share of debt relief in a donor's total ODA and the volatility of aid excluding debt relief is 0.71 . However, this result should be interpreted with caution, because the paucity of continuous data on debt relief reduces the sample size of major donors to 13 . There is an additional bias in that only countries that have been active in debt relief are likely to report data. Even in this reduced sample, aid volatility in countries such as Australia, Canada, and Japan whose ratios of debt relief to ODA are lower than the median, is also lower than the median. 
Figure 13. Volatility of Aid Excluding Debt Relief and

Debt Relief as a Share of ODA, 2000-03

(In percent)

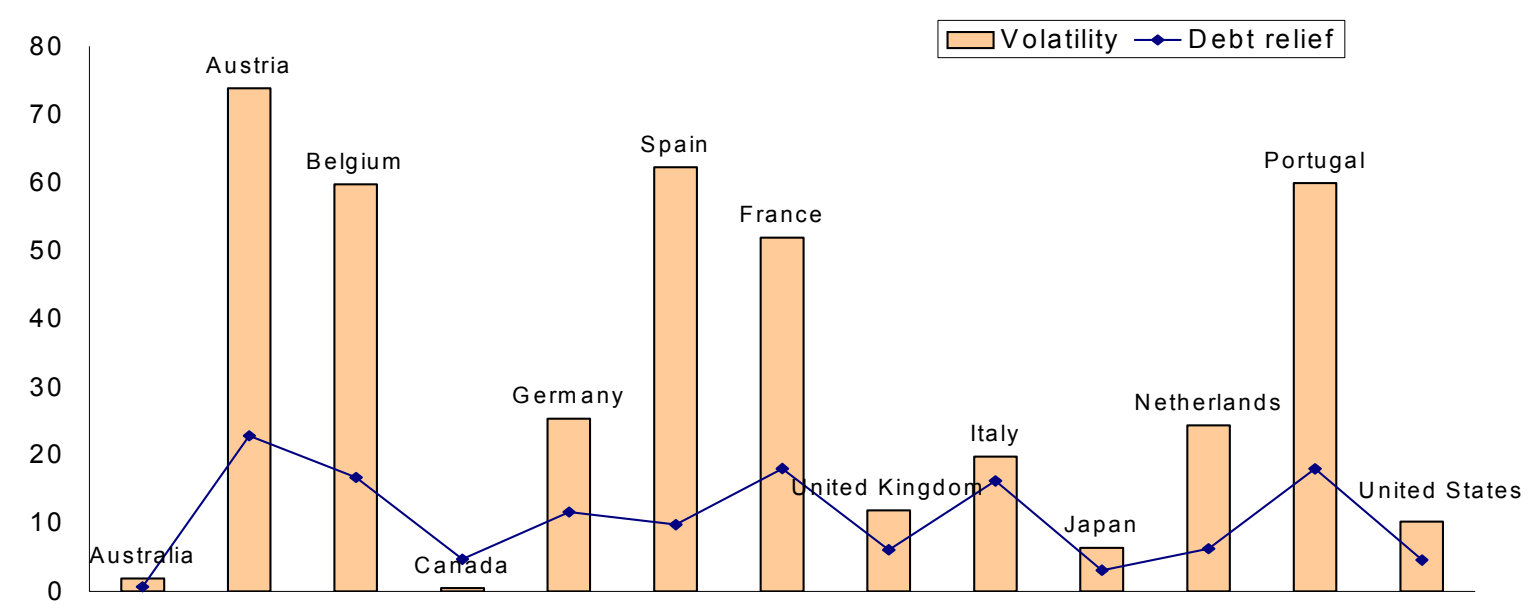

Sources: OECD, 2005; IMF staff calculations.

Note: Aid volatility is measured by standard deviation, in percent.

\section{Concluding Remarks}

There has been a renewed discussion of the role of ODA in reducing poverty. The enthusiasm for this renewed impetus to increase the quantity and quality of aid however, is not universal. ${ }^{27}$ Critics have argued that similar efforts in the past have yielded very little in the way of results and that, after more than four decades, there is little evidence that aid has led to significant poverty reduction.

Nevertheless, it is useful to look at the extent to which the scaling up of aid flows and trends in the destination and composition of aid are likely to improve aid effectiveness. Our analysis indicates that, since the 1960s, the volume of aid has increased, albeit with some interruptions. In particular, for several years in the 1990s, aid flows declined in real terms. The unweighted aid effort for DAC countries in 2004 was 0.42 percent of GNI, and the income-weighted average was 0.25 percent, implying that smaller donors are leading the aid effort. Over time, the major recipients of aid have changed: while the share of Asian countries has diminished sharply since the 1980s, that of sub-Saharan Africa has grown. There is some evidence that since the late 1990s, debt relief has played an important role in the increased aid flows to sub-Saharan Africa. The share of technical cooperation, a component of aid that is seen to be driven by

\footnotetext{
${ }^{27}$ Easterly has been particularly vocal in his criticism of recent initiatives to increase the volume of aid as being part of the long-standing practice in the donor community of "letting total aid money stand for accomplishment" (http://www.thes.co.uk March 11 (2005). For a more rigorous treatment of similar ideas, see Easterly (2003) and Easterly, Levine, and Roodman (2004).
} 
donors, has risen. More recently, there has been an increased emphasis on providing budget support to recipient governments, especially in the form of debt relief.

For aid to play a significant role in poverty reduction, the proposed scaling up should be accompanied by a close examination of practices that have hampered cou,ntries' ability to use aid effectively in the past. Harmonization of donor practices and alignment of aid flows with the priorities of recipient countries can enhance aid effectiveness. EU donors have been particularly active in mapping out a medium-term strategy that coordinates the efforts of major donors. National ownership and leadership of development plans is crucial for aid to be effective. For their part, recipient countries face challenges in instituting the necessary policy reforms and strengthening governance and public expenditure management systems to effectively absorb the rising aid flows and maximize their impact on poverty. 


\section{References}

Adam, Christopher, 2005, "Exogenous Inflows and Real Exchange Rates: Theoretical Quirk or Empirical Reality?" prepared for the Seminar on Foreign Aid and Macroeconomic Management, organized by the IMF Institute and the African Department March 14-15, 2005.

Addison, Tony, George Mavrotas, and Mark McGillivray, 2005, Aid, Debt Relief and New Sources of Finance for Meeting the Millennium Development Goals," WIDER Research Paper No. 2005/09 (Helsinki, Finalnd: World Institute for Development Economics Research, United Nations University).

Adelman, Carol, 2003, “The Privatization of Foreign Aid,” Foreign Affairs, Vol. 83 (6), pp. 9-14.

Ajayi, S. Ibi, and Afeikhena Jerome, 2002, "Opportunity Costs and Effective Markets," Development Policy Journal, Vol. 2 (Special Issue: Technical Cooperation), pp. 23-46.

Alesina, Alberto, and David Dollar, 1998, "Who Gives Foreign Aid to Whom and Why," NBER Working Paper No. 6612 (Cambridge, Massachusetts: National Bureau of Economic Research).

Atkinson, A.B., 2005, "The Way Forward," in New Sources of Development Finance, ed. by A.B. Atkinson (New York: Oxford University Press), pp. 238-46.

Berg, Elliot, 1993, Rethinking Technical Cooperation: Reforms for Capacity Building in Africa (New York: United Nations Development Program).

Bulìr, Aleś, and A. Javier Hamann, 2005, "Volatility of Development Aid: From the Frying Pan into the Fire?" prepared for the Seminar on Foreign Aid and Macroeconomic Management, organized by the IMF Institute and African Department, March 14-15, 2005.

Bulìr, Aleś, and Timothy Lane, 2002, “Aid and Fiscal Management,” IMF Working Paper 02/112 (Washington: International Monetary Fund).

Burnside, Craig, and David Dollar," 2000, Aid, Policies and Growth," American Economic Review, Vol. 90 (September), pp. 847-68.

Chang, Charles C., Eduardo Fernandez-Arias, and Luis Serven, 1998 "Measuring Aid Flows: A New Approach,” Research Paper No. 387 (Washington: Inter-American Development Bank); http://www.worldbank.org/research/growth/pdfiles/chang.pdf. 
Chauvet, Lisa, and Patrick Guillaumont, 2002, "Aid and Growth Revisited: Policy, Economic Vulnerability and Political Instability," presented at Annual Bank Conference on Development Economics, Oslo.

Clemens, Michael, Steven Radelet, and Rikhil Bhavnani, 2004, "Counting Chickens When They Hatch: The Short Term Effect of Aid on Growth," CGD Working Paper No 44 (Washington: Center for Global Development).

Collier, Paul, and Jan Dehn, 2001, “Aid, Shocks, and Growth,” Policy Research Working Paper No. 2688 (Washington: World Bank).

Commission for Africa, 2005, Our Common Interest: Report of the Commission for Africa (London: Department for International Development (DFID).

Commission of the European Communities, 2005, "EU Strategy for Africa: Towards a EuroAfrican pact to accelerate Africa's development"; http://europa.eu.int/comm/development/body/communications/docs/eu_strategy_for_afri ca_12_10_2005_en.pdf\#zoom $=100$.

Cordella, Tito, and Giovanni Dell'Ariccia, 2003, "Budget Support Versus Project Aid," IMF Working Paper No. 03/88 (Washington: International Monetary Fund).

Dalgaard, Carl-Johan, Henrik Hansen, and Finn Tarp, 2004, "On the Empirics of Foreign Aid and Growth,” Economic Journal, Vol. 114 (June), pp. F191-F216.

Devarajan, Shantayanan, and Vinaya Swaroop, 1998, “The Implications of Foreign Aid Fungibility for Development Assistance,” Policy Research Working Paper No.2022 (Washington: World Bank).

Dollar, David, and Victoria Levin, 2004, “ The Increasing Selectivity of Foreign Aid, 19842002,” Policy Research Working Paper No. 3299 (Washington: World Bank).

Easterly William, 2003, "Can Foreign Aid Buy Growth?" Journal of Economic Perspectives, Vol. 17 (Summer), pp. 23-48.

_ , "Money Is Not a Cure-All for Africa's Poor, 2005," Times Higher Education Supplement, http://www.thes.co.uk March 11, 2005.

- Ross Levine, and David Roodman, 2004, "Aid, Policies and Growth: Comment," American Economic Review, Vol. 94 (3), pp. 774-780.

Economist, “Those Stingy Americans," 2005, Economist Print Edition, May 26.

Eifert, Benn, and Alan Gelb, 2005, "Improving the Dynamics of Aid: Towards More Predictable Budget Support" (draft: World Bank). 
Fielding, David, and George Mavrotas, 2005, "The Volatility of Aid," WIDER Research Paper No. 2005/09 (Helsinki, Finalnd: World Institute for Development Economics Research, United Nations University).

Gates, Scott, and Anke Hoeffler, 2004, "Global Aid Allocation: Are Nordic Donors Different?" CSAE Working Paper 2004-34. (Oxford, United Kingdom: Center for the Study of African Economics).

Guillaumont, Patrick, and Lisa Chauvet, 2001, "Aid and Performance: A Reassessment," Journal of Development Studies, Vol. 37 (August), pp. 66-92.

Gupta, Sanjeev, Benedict Clements, and Erwin R. Tiongson, 2004, "Foreign Aid and Consumption Smoothing: Evidence from Global Food Aid," Review of Development Economics, Vol. 8 (August), pp. 379-90.

Gupta, Sanjeev, Erik Lueth, and Qiang Cui, 2004, “Is Less Technical Cooperation More? Freeing Resources for the Millennium Development Goals" (draft; Washington: International Monetary Fund).

Hartford, Tim, Bita Hadjimichael, and Michel Klein, 2004, "The Supply of Aid," Public Policy for the Private Sector, October .

Hartford, Tim, and Michael Klein, 2004 "Donor Performance," Public Policy for the Private Sector, October (2004).

Hauge, Arild O., 2002, “Accountability - to What End," Development Policy Journal, Vol. 2 (Special Issue: Technical Cooperation), pp. 73-94.

International Monetary Fund, 2005, World Economic Outlook April 2005 (Washington: International Monetary Fund).

Islam, Muhammed, 2003, "Political Regimes and the Effect of Foreign Aid on Economic Growth," Journal of Developing Areas, Vol. 37 (1), pp. 35-53.

Lensink, Robert, and Oliver Morrisey, 2000, "Aid Instability as a Measure of Uncertainty and the Positive Impact of Aid on Growth," Journal of Development Studies, Vol. 36 (February), pp. 31-49.

Mavrotas, George, 2005, "The International Finance Facility Proposal," in New Sources of Development Finance, ed. by A.B Atkinson (New York: Oxford University Press), pp. 110-131.

McGillivray, Mark,2003a "Modelling Aid Allocation: Issues, Approaches and Results," Journal of Economic Development, Vol. 28 (1), pp.171-88. 
,2003b, “Aid Effectiveness and Selectivity: Integrating Multiple Objectives into Aid Allocations, " Summary Paper presented at Joint OECD DAC/Development Experts' Seminar on Aid Effectiveness and Selectivity, Paris, March.

— , 2004, and Edward Sefuke, "Multilateral Development Assistance: Good, Bad and Just Plain Ugly?,” http://www.eu-ldc.org/conference/ conference2004/session7.php.

Micklewright, John, and Anna Wright, 2005, "Private Donations for International Development," in New Sources of Development Finance ed. by A.B Atkinson (New York: Oxford University Press), pp.132-155.

Morgan, Peter, 2002, “Technical Assistance: Correcting the Precedents," Development Policy Journal, Vol. 2 (Special Issue: Technical Cooperation), pp.1-22.

Organization for Economic Cooperation Development (OECD), 2005, "Donors Increase Aid But 2006 a Challenge," DAC News, April-May; http://www.oecd.org/dataoecd/34/52/34682343.htm.

Pallage, Stephane, and Michel Robe, 2001, "Foreign Aid and the Business Cycle," Review of International Economics, Vol. 9 (November), pp. 636-67.

— 2003, "On the Welfare Cost of Economic Fluctuations in Developing Countries," International Economic Review, Vol. 44 (May), pp. 677-98.

Prati, Alessandro, Ratna Sahay, and Thierry Tressel, 2003, "Is There a Case for Sterilizing Foreign Aid?” (mimeo; Stockholm: European Economic Association).

Radelet, Steven, 2004, “Aid Effectiveness and the Millennium Development Goals,” CGD Working Paper No 39 (Washington: Center for Global Development).

Rajan, Raghuram G., and Arvind Subramanian,2004, "What Prevents Aid From Enhancing Growth?” (draft; Washington: International Monetary Fund).

Ratha, Dilip, 2003 “Workers' Remittances," in Global Development Finance 2003: Striving for Stability in Development Finance (Washington: World Bank).

Roodman, David, 2004, “An Index of Donor Performance,” CGD Working Paper No. 42 (Washington: Center for Global Development).

United Nations Development Group (UNDG), 2005, Paris Declaration on Aid Effectiveness.

UN Millennium Project, Millennium Project Report 2005: A Practical Plan to Achieve the Millennium Development Goals (New York: United Nations). 
White, Howard, 2002, "Long-run Trends and Recent Developments in Official Assistance from Donor Countries," WIDER Discussion Paper 2002/106 http://www.wider.unu.edu/publications/publications.htm.

World Bank, Global Development Finance 2005: Managing Vulnerability, (Washington: World Bank).

World Bank-IMF, Global Monitoring Report 2005 (Washington: World Bank). 